\title{
Vplyv špecifických tréningových podnetov na individuálný herný výkon juniorského brankára vo futbale
}

\section{Influence of a specific training incentives on youth goalkeeper's individual game performance in football}

\author{
Pavol Peráček, Pavol Hrnčiarik \\ Fakulta telesnej výchovy a športu Univerzity Komenského, Bratislava, Slovensko
}

\begin{abstract}
Abstrakt
Výskum bol orientovaný na problematiku športovej prípravy juniorských brankárov vo futbale. Išlo o dvojskupinový časovo súbežný pedagogický experiment v prirodzených podmienkach tréningového procesu. Zist'ovali sme vplyv experimentálneho činitel'a na dynamiku zmien hernej výkonnosti brankárov pomocou hodnotenia individuálneho herného výkonu (d’alej len „IHV“) brankára. Experimentálny činitel’ v našom pedagogickom experimente bol obsah špeciálnej prípravy brankára, ktorý sa prejavil v technicko-taktickej príprave rozdielnym zastúpením útočných herných činností brankára a obranných herných činností brankár a medzi experimentálnym a kontrolným súborom. Pri jeho koncipovaní sme vychádzali z viac ako 100 analýz IHV juniorských a seniorských brankárov na vrcholových podujatiach. Dosiahnuté výsledky sme analyzovali a porovnávali s výsledkami kontrolného súboru. Dospeli sme k záverom, že tréningový program experimentálneho súboru s akcentom na útočné herné činnosti mal štatisticky významný vplyv na individuálny herný výkon brankárov v majstrovských zápasoch.
\end{abstract}

\begin{abstract}
The research focused on the sport training issue of junior goalkeepers in football. It was a two-group, time-parallel pedagogical experiment in natural conditions of the training process. We surveyed the impact of experimental factor on the dynamics of changes in game performance of goalkeepers with using individual game performance evaluation and expertise method - individual game performance evaluation. The content of special training of goalkeeper was the experimental factor in our pedagogical experiment. The experimental factor appeared differently in experimental and control group. In the technical and tactical preparation it appeared with a different representation of the offensive and defensive activities of goalkeeper. We based composing the experimental factor on more than 100 analyzes of individual game performance of junior and senior goalkeepers in top events. The results obtained during research were analyzed and compared with the results of the control group. We conclude that the training program of experimental group with emphasis on offensive game activities had a statistically significant impact on individual game performance of goalkeepers in the match.
\end{abstract}

Kl'účové slová: futbal, brankár, tréning brankára, individuálny herný výkon brankára.

Key words: football, goalkeeper, goalkeeper training, goalkeeper's individual game performance.

\section{TEORETICKÉ VÝCHODISKÁ}

Hráčske funkcie vo futbale a ich vývoj je úzko spätý s vývojom herných systémov. Vo futbale je vel'ký počet hráčskych funkcií. Lišia sa podl'a autorov, ale aj podl'a daného herného systému. Každý herný systém môžeme charakterizovat' ako základné organizované rozostavenie hráčov na ihrisku, ktorým sú pridelené úlohy vyplývajúce z ich hráčskych funkcií (PERÁČEK, 2004/a).

Oficiálne je brankár vo futbale hráčskou funkciou, ktorá vznikla na základe úpravy pravidiel v roku 1871, kedy bolo ustanovené, že 1 hráč na ihrisku môže chytat' loptu do rúk aj ked' je dôležité poznamenat', že tejto 
úprave pravidiel predchádzala ešte jedna dôležitá úprava z roku 1870, ktorá zakazuje hráčom v poli používanie rúk, čím brankár vlastne získal prvú výhodu oproti hráčom v poli. Od tej doby prišlo v tejto hráčskej funkcii $\mathrm{k}$ tol'kým zmenám ako v žiadnej inej hráčskej funkcii hráča v poli.

Vyššie uvedené pravidlá postupne rozširovali úlohy brankára v zápase. Úloha brankára je nad’alej najmä obranná, avšak svojim postavením na ihrisku má aj úlohu pozorovatel’a, čo využíva pri zakladaní útoku. Nároky na hru brankára ako v obrane, tak hlavne v útočnej fáze sa zväčšujú (konštruktívny rozohrávač lopty prvým dotykom a pod.) (DESHORS, 1997; VOTÍK, 2003; SMITH, 2004).

V hre neexistuje typologicky „čistý“ stredný obranca alebo typický stredný útočník. Brankár je jediný špecialista $v$ hre. V prvom rade je hráčom, ktorý sám rozhodujúcou mierou môže ovplyvnit’ priebeh stretnutia (HAZLEWOOD, 1998; RUIZ, 2001; STEINER, 2005).

Niektorí autori charakterizujú štruktúru herného výkonu v športových hrach ako jednotu vykonania a výsledku určitej činnosti alebo určitého komplexného sledu činností, ktoré sú merané či hodnotené na základe určitých sociálne determinovaných noriem, alebo ako vnútorná stavba vzájomne sa podmieňujúcich a optimálne sa prejavujúcich faktorov (elementov, zložiek), ktoré sú potrebné na dosiahnutie konkrétneho výkonu. Herný výkon sa realizuje v špecifických pohybových činnostiach, kde jeho obsahom je riešenie úloh, ktoré sú vymedzené pravidlami príslušného športu a v nich sa športovec usiluje o maximálne uplatnenie výkonových predpokladov (SLOVÍK, 1989; SCHNABEL et al., 1994; STEIHLER - KONZAG, 1994; DOVALIL et al., 2002).

Hodnotenie herného výkonu slúži na posúdenie účinnosti stratégie a taktiky hry vlastného družstva i súpera, na zist'ovanie vývojových tendencií hry a pod.. Je cenným zdrojom informácií na vyhodnotenie účinnosti tréningového procesu a jeho prípadné následné korekcie. V športových hrách všeobecne patrí hodnotenie herného výkonu medzi základné otázky teoretického i praktického charakteru (EJEM, 1970; HOHMANN - BRACK, 1983; DOBRÝ - SEMIGINOVSKÝ, 1988; REILLY, 1994).

Diagnostická činnost’ je zacielená na hodnotenie hráča v zápase a v tréningovom procese. Vedie k poznaniu aktuálnej formy hráča, ale aj k porovnávaniu získaných informácií s predchádzajúcimi, na základe čoho sa hráči zarad’ujú do určitej skupiny, kategórie (KAČÁNI, 2000; KORMANÍK, 2006). Pochopenie herného výkonu najúspešnejších družstiev spočíva $\mathrm{v}$ pochopení herného výkonu hráčov v jednotlivých hráčskych funkciách. Moderný spôsob riadenia prípravy je nemyslitel'ný bez priebežného dodávania množstva rôznych informácií. To sa týka každej hráčskej funkcie v družstve, teda i brankára (BRÜEGGEMANN, 2008).

\section{CIEL' VÝSKUMU}

Ciel’om našej práce bolo rozšírit' a prehĺbit' poznatky o vplyve špecifických tréningových podnetov na zmenu úrovne individuálneho herného výkonu juniorského brankára v zápase.

\section{HLAVNÁ HYPOTÉZA PRÁCE}

Predpokladáme, že tréningový program juniorských brankárov s akcentom na útočné herné činnosti bude mat’ štatisticky významný vplyv na vybrané ukazovatele individuálneho herného výkonu experimentálneho súboru v zápase.

\section{ČIASTKOVÉ HYPOTÉZY PRÁCE}

1) Predpokladáme štatisticky významné zlepšenie experimentálneho súboru v útočných herných činnostiach brankára v zápase po absolvovaní tréningového programu.

2) Predpokladáme, že vplyv experimentálneho činitel'a nebude mat' štatisticky významný vplyv na obranné herné činnosti brankárov experimentálneho súboru v zápase po tréningovom programe.

3) Predpokladáme štatistické významné zlepšenie experimentálneho súboru oproti kontrolnému súboru v hodnotení úrovne vybraných charakteristík IHV v zápase po tréningovom programe.

4) Predpokladáme, že experimentálny súbor bude v porovnaní s kontrolným súborom štati sticky úspešnejší v expertíznom hodnotení individuálneho herného výkonu v sledovaných zápasoch po tréningovom programe. 


\section{ÚLOHY PRÁCE}

Z ciel’a práce vyplývajú nasledujúce úlohy:

1. Vypracovat' a v praxi zrealizovat' tréningový program $\mathrm{s}$ akcentom na útočné herné činnosti brankára.

2. Vypracovat' zberné hárky na evidenciu a hodnotenie individuálneho herného výkonu brankára $\mathrm{v}$ zápase.

3. Po absolvovaní pedagogického experimentu porovnat' zastúpenie tréningových ukazovatel’ov v športovej príprave experimentálneho a kontrolného súboru.

4. Zistit' dynamiku zmien hernej výkonnosti experimentálneho a kontrolného súboru v zápasoch, pomocou hodnotenia IHV brankára a expertízneho hodnotenia IHV.

5. Po realizácii pedagogického experimentu porovnat' výsledky hodnotenia IHV brankára a expertízneho hodnotenia IHV medzi experimentálnym a kontrolným súborom.

6. Na základe dosiahnutých výsledkov formulovat’ závery pre rozvoj vedného odboru a športovej praxe

\section{METODIKA PRÁCE A METÓDY SKÚMANIA}

Ako metódu výskumu sme zvolili pedagogický experiment v prirodzených podmienkach tréningového procesu a zápasu, na základe ktorého sme overili účinnost' tréningového prípravy brankára z hl’adiska hernej výkonnosti v zápase. Výskumné sledovanie malo charakter súbežného dvojskupinového pedagogického experimentu, ktorého úlohou bolo posúdit' efektívnost' experimentálneho programu prípravy brankára v porovnaní s tradičným kontrolným programom prípravy brankára, doteraz uplatňovaným v praxi. Pedagogický experiment sme uskutočnili v podmienkach pravidelnej tréningovej činnosti.

Na získanie výskumných údajov sme použili nepriame, časovo odložené pozorovanie. Monitorovali sme pohybové zat’aženie (herné činnosti) - ktoré sme chápali ako aktiváciu metabolických a nervovo-svalových funkcií s takou vol'bou a počtom sledovaných herných znakov, aby sme zachovali prirodzenost' postihovanej hernej činnosti a súčasne kvalitu tohto hodnotenia. Observačná analýza herných činností nám umožnila získat' komplexnejšiu informáciu o modeloch vonkajšieho zat’aženia brankárov juniorskej kategórie (herná aktivita) - v priebehu času (frekvencia) a mieste uskutočnenia (lokalizácia). (PERÁČEK - HRNČIARIK, 2010)

V priebehu pedagogického experimentu sme pôsobili na experimentálny súbor brankárov (ES) experimentálnym podnetom (EP), a na kontrolný súbor brankárov (KS) kontrolným podnetom (KP), ktorých pôsobenie sme sledovali na zmenách úrovne individuálnych herných výkonov brankárov v zápase $(\mathrm{z} 1, \ldots \mathrm{z} 6) \mathrm{v}$ časových intervaloch Dt0 a Dt1.

Schéma výskumnej situácie (majstrovské zápasy):

ES: Dt0 $(\mathrm{z} 1, \ldots \mathrm{z} 6)=>\mathrm{EP}=>$ Dt $1(\mathrm{z} 1, \ldots \mathrm{z} 6)$

KS: Dt0 $(z 1, \ldots z 6)=>$ KP $=>$ Dt $1(z 1, \ldots z 6)$

\section{CHARAKTERISTIKA SÚBORU}

Výskum je orientovaný na mladých brankárov, preto sme na základe zámerného výberu stanovili experimentálny a kontrolný súbor, ktorých brankári patria do kategórie juniorov.

Experimentálny súbor (ES) tvorili 3 brankári družstva staršieho a mladšieho dorastu FC Petržalka 1898, ktorých priemerný kalendárny vek bol 18,3 a priemerná hráčska prax bola 8,7 roka. Družstvo v sút’ažnom ročníku 2010/2011 bolo účastníkom druhej najvyššej sút’aže tejto vekovej kategórie - II. Ligy staršieho a mladšieho dorastu - západ.

Kontrolný súbor (KS) tvorili 3 brankári družstva staršieho a mladšieho dorastu FK Púchov, ktorých priemerný kalendárny vek bol 18,6 a priemerná hráčska prax bola 9,1 roka. Družstvo v sút’ažnom ročníku 2010/2011 bolo účastníkom druhej najvyššej sút’aže tejto vekovej kategórie - II. Ligy staršieho a mladšieho dorastu - západ.

\section{CHARAKTERISTIKA EXPERIMENTÁLNEHO ČINITELA}

Pri konštrukcii obsahu špeciálnej prípravy brankára sme sa snažili o vypracovanie takého programu prípravy, ktorého realizáciou môžeme rozvíjat' herné činnosti, pohybové schopnosti a herné zručnosti vyplývajúce 
z vývojových tendencii pre sledovanú hráčsku funkciu.

Ako experimentálny činitel' v našom pedagogickom experimente sme stanovili obsah špeciálnej prípravy brankára v družstve FC Petržalka 1898. Pri koncipovaní plánu tréningovej prípravy sme využili aj naše poznatky o hernom výkone brankára z pohl'adu proporcionality herných činností. Tieto fakty sa v tréningovom programe experimentálneho súboru prejavili väčším zastúpením útočných herných činností brankára oproti obranným herným činnostiam brankára.

Uplatnením experimentálneho činitel'a sme sa snažili v priebehu experimentu akcentovat':

a) Štrukturalizáciu obsahu športového tréningu, ktorá sa týkala logického usporiadania obsahu a určenia počtu tréningových hodín pre osvojovanie útočných a obranných herných činností brankára.

b) Funkčnost' tréningového programu, ktorá smerovala $\mathrm{k}$ výberu a k optimalizácii proporcionality foriem cvičení a ich výberu. Tieto by mali vysokú afinitu $\mathrm{k}$ takej proporcionalite herných činností ktorá napíña teóriu adekvátneho krytia.

Experimentálny obsah športovej prípravy (obr. 1) charakterizovala tendencia, aby formovanie a rast herného výkonu brankára prebiehali v prevažnej miere v súlade s požiadavkami hry. Aplikovanými metodicko - organizačnými formami cvičení sme nacvičovali a zdokonal'ovali všetky stránky herných činnosti brankára komplexnejšie, v priestorovej a časovej tiesni. Tým sa do určitej miery prenášala do tréningového procesu jedinečná funkcia stretnutia spojená so stálou neistotou, rizikom a situačne špecifickými požiadavkami na okamžitý úspech pri riešení herných situácií (PERÁČEK, 1992).

Obrázok 1 - Pomer kondičnej a technicko-taktickej prípravy (v minútach) v TP experimentálneho súboru (ES)

\section{Experimentálny súbor (min,\%)}

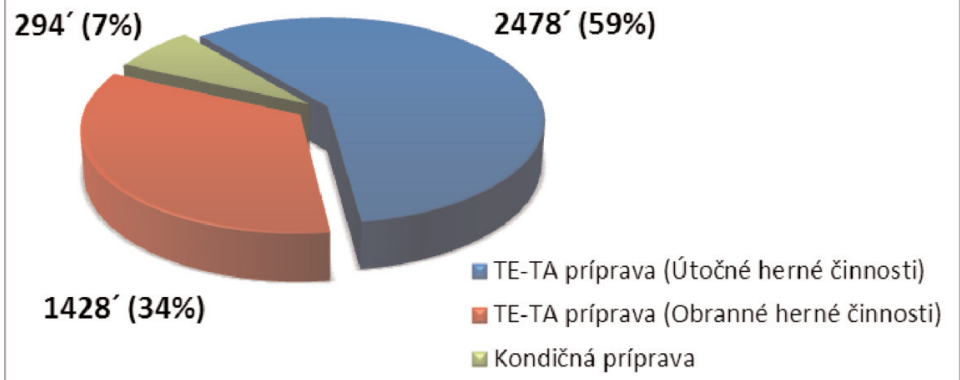

\section{KONTROLNÝ PODNET}

Obrázok 2 - Pomer kondičnej a technicko-taktickej prípravy (v minútach) v TP kontrolného súboru (KS)

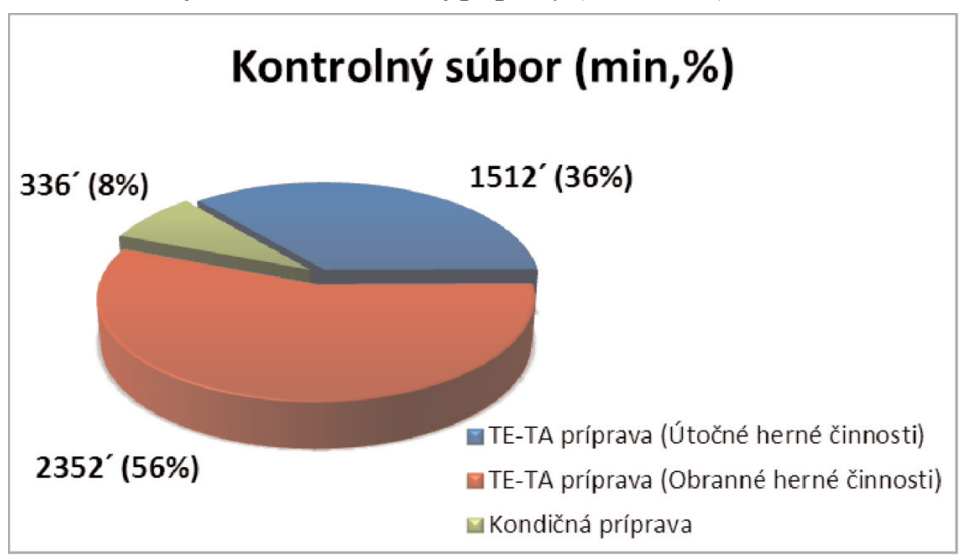

Tréningový program kontrolného súboru (Obr. 2) vychádzal z tradičnej prípravy brankára. Takýto tréningový program vychádza z nácviku a zdokonal'ovania takých obranných herných činností brankára ktoré riešia priame ohrozenie brány. Zdokonal'ovanie útočných herných činnosti je zamerané predovšetkým na základné spôsoby zakladania útoku, v záverečnej časti špeciálnej tréningovej jednotky brankára. 


\section{METÓDY ZÍSKAVANIA VÝSKUMNÝCH ÚDAJOV}

V práci sme použili súbežný dvojskupinový pedagogický experiment na dvoch výberoch brankárov, kde brankári FK Púchov vystupovali ako kontrolný a brankári FC Petržalka 1898 ako experimentálny súbor. V kontrolnom súbore sme uplatnili v obsahu tradičné tréningové podnety využívané v tréningovej praxi a v experimentálnom súbore experimentálny podnet.

\section{- Pozorovanie}

Ďalšiu metódu ktorú sme použili bola metóda observačnej analýzy. Observačnou analýzou pohybovej aktivity hráčov sme sa zamerali na sledovanie pohybovej aktivity brankárov v priebehu zápasu s ciel'om získat' informácie o vybraných herných činnostiach brankára (o počte a skladbe týchto herných činností) tak, aby sme mohli okrem iného charakterizovat' typický model pohybovej aktivity brankára. Tieto poznatky smerovali k interpretácii pohybových nárokov na individuálny herný výkon brankára a jeho implikáciu do tréningového procesu (GAVORA, 1998 in ŠVEC a kol.; BENČO, 2001; WHALL, 2001; KONČEK, 2004).

\section{HODNOTENIE INDIVIDUÁLNEHO HERNÉHO VÝKONU BRANKÁRA V ZÁPASE}

Pomocou zámerného nepriameho pozorovania spojeného s metódou záznamu sme hodnotili sledované ukazovatele herného výkonu brankára vo vybraných herných činnostiach počas celého stretnutia, ako aj kvalitu vykonávaných herných činností. Pomocou štatistického záznamu sme evidovali herný výkon brankára vo vybraných ukazovatel'och (TARKOVIČ, 2000):

-ÚHČ - HČ nohou (RN), HČ rukou (RR) a HČ výkop z ruky (VR)

-OHČ - HČ chytanie strely (SCH), HČ vyrážanie strely (SV), HČ chytanie finálnej prihrávky $(\mathrm{CCH})$, HČ vyrážanie finálnej prihrávky (CV), HČ vybiehanie proti lopte $(\mathrm{V})$

Početnost' a kvalitu vybraných ukazovatel'ov herného výkonu sme zaznamenávali do pripravených záznamových hárkov. $\mathrm{V}$ práci sme použili jednoznačné hodnotenie vybraných herných činností brankára (+/-). Znamienkom „,+“ sme označili úspešnú, presnú činnost’ a znamienkom ,--“neúspešnú, nepresnú činnost’. Počet kladných a záporných znamienok sme sčítali a vyjadrili percentom úspešnosti brankára vo vybraných ukazovatel’och. Táto metóda na registráciu a hodnotenie vybraných herných činností brankára nám slúžila ako podklad o nových poznatkoch o lokalizácii herných činností brankára.

Vybrané ukazovatele herného výkonu brankára sme začali sledovat' v majstrovských zápasoch v hlavného obdobia I. sezóny 2010/2011. Druhú čast’ sledovania sme uskutočnili v hlavnom období II. sezóny 2010/2011. Brankárov experimentálneho, aj kontrolného súboru sme sledovali v 6 zápasoch v čase Dt0 (hlavné obdobie I) a v 6 zápasoch v čase Dt1 (hlavné obdobie II).

\section{- Metóda expertízneho hodnotenia}

1. Jedna zo základných výskumných úvah pri koncipovaní výskumnej stratégie bolo použitie metódy expertízneho hodnotenia individuálneho herného výkonu, (KORČEK, 1987; KAČÁNI - PERÁČEK, 1989; KAČÁNI, 1991) v majstrovských zápasoch.

2. Už pri prvotných úvahách o výbere expertov pre tento výskum sme uvažovali o ich zodpovedajúcej kvalite. Významným aspektom bolo, všetci experti mali nami požadované kvalifikačné predpoklady (držitelia EURO A a EURO PRO licencie s primeranou trénerskou praxou od 8 do 20 rokov. Dôležitým aspektom bolo tiež to, že okrem dlhoročných skúseností s prácou s talentovanými brankármi, pracovali všetci experti aktuálne v danej problematike. Tým boli ich vedomosti a skúsenosti podrobované každodennej konfrontácii $\mathrm{s}$ tréningovou a zápasovou praxou. V nasledujúcej časti práce uvádzame aj verbálnu charakteristiku jednotlivých škál.

\section{Brankár chytal výborne (bol oporou mužstva)}

- Úspešnost' hodnotenia OHČ a ÚHČ bola $90 \%$ a viac.

- Ovládal celé pokutové územie, pôsobil isto a spol'ahlivo.

- Správne vykrýval strelecké uhly, dodržiaval zásadu dvojitého krytia lopty.

- V kritických herných situáciách použil adekvátnu hernú činnost' jednotlivca so správnym technickým vykonaním.

- Obranné herné činnosti ktoré v zápase v herných situáciách použil, boli takticky správne vybrané a technicky správne realizované, a prospešné pre obrannú fázu hry.

- Útočné herné činnosti, ktoré v zápase použil boli takticky správne vybrané a technicky správne vykonané. 
- Verbálne, aj neverbálne organizoval obrannú i útočnú činnost' družstva

2. Brankár chytal vel'mi dobre (bez výraznejších chýb)

- Úspešnost' hodnotenia OHČ a ÚHČ bola $80 \%$ až $89 \%$.

- Ovládal celé pokutové územie, pôsobil isto a spol'ahlivo.

- Správne vykrýval strelecké uhly, dodržiaval zásadu dvojitého krytia lopty

- Pri kritickej hernej situácii použil adekvátnu hernú činnost' jednotlivca so správnym tech nickým vykonaním.

- Obranné herné činnosti, ktoré v zápase použil, boli takticky správne vybrané a technicky správne realizované.

- Útočné herné činnosti, ktoré v zápase realizoval, boli takticky správne vybrané a technicky vo väčšine prípadov správne vykonané.

- Verbálne, aj neverbálne organizoval obrannú i útočnú činnost' družstva

\section{Brankár chytal dobre (avšak s malými chybami, ktoré ale neovplyvnili výsledok v zápase)}

- Úspešnost' hodnotenia OHČ a ÚHČ bola 70\% až 79\%.

- Nevykonal správne hernú činnost' - vybiehanie proti lopte.

- Obranné herné činnosti, ktoré v zápase použil, boli takticky správne vybrané a technicky správne realizované.

- Útočného herné činnosti, ktoré v zápase realizoval boli takticky správne vybrané a technicky nie vždy správne vykonané.

- Verbálne, aj neverbálne organizoval obrannú i útočnú činnost' družstva

\section{Brankár chytal zle (nepodržal mužstvo)}

- Úspešnost' hodnotenia OHČ a ÚHČ bola $50 \%$ a $69 \%$.

- Váhal a často nesprávne vykonal hernú činnost' - vybiehanie proti lopte.

- Použil neadekvátnu hernú činnost' brankára síce so správnym technickým vykonaním, ale s ne správnym taktickým rozhodnutím a tým nesprávne vyriešil kritickú hernú situáciu a ov plyvnil výsledok zápasu. Obranné herné činnosti, ktoré v zápase použil, boli takticky správne vybrané a technicky nesprávne realizované.

- Útočné herné činnosti, ktoré v zápase použil, boli takticky správne vybrané a technicky tak mer vždy nesprávne vykonané.

- Neorganizoval verbálne aj neverbálne obrannú a útočnú hernú činnost' družstva.

\section{Brankár chytal vel'mi zle (dopustil sa hrubých chýb)}

- Úspešnost' hodnotenia OHČ a ÚHČ bola 49\% a menej.

- Používal neadekvátnu hernú činnost' brankára v kritických herných situáciách s nesprávnym technickým vykonaním, čím zapríčinil inkasovaný gól.

- Obranné herné činnosti, ktoré v zápase použil, boli takticky nesprávne vybrané a technicky nesprávne realizované.

- Útočné herné činnosti, ktoré v zápase použil boli často takticky nesprávne vybrané a technicky takmer vždy nesprávne vykonané.

- Neorganizoval verbálne aj neverbálne obrannú a útočnú hernú činnost’ družstva.

\section{METÓDY SPRACOVANIAA VYHODNOTENIA VÝSKUMNÝCH ÚDAJOV}

Na spracovanie a vyhodnotenie zistených údajov sme použili základné metódy logickej a vecnej analýzy, najmä analýzu a syntézu, indukciu a dedukciu, zovšeobecňovanie, hl'adanie príčinných súvislostí a pod. Ďalej sme sa opierali o nasledovné matematické a štatistické charakteristiky:

- $\quad$ aritmetický priemer,

- smerodajnú odchýlku,

- pri testoch štatistickej významnosti sme použili:

- parametrický Wilcoxonov T-test pri sledovaní dynamiky zmien v rámci expertízneho hodnotenia brankárov,

- Kendallow koeficient zhody pri posúdení objektívnosti hodnotenia expertov

- Chi-kvadrát, test dobrej zhody pri sledovaní zmien stavov - obranných a útočných herných činností brankára v zápase. 


\section{ORGANIZÁCIA A ZABEZPEČENIE PEDAGOGICKÉHO EXPERIMENTU}

Vlastný pedagogický experiment prebiehal v podmienkach pravidelnej tréningovej činnosti v sezóne 2010/2011. Počet tréningových jednotiek bol v oboch súboroch rovnaký (2 krát do týždňa - pondelok a štvrtok).

Každého brankára experimentálneho a kontrolného súboru sme sledovali v 6 majstrovských zápasoch v čase Dt0 (HO I) a v 6 zápasoch v čase Dt1 (HO II).

Sledovanie experimentálneho a kontrolného súboru v sút’ažnom ročníku 2010/2011:

Vstupné hodnotenie (Dt0)

Začiatok HO I (Júl 2010 - September 2010)

- Vstupné hodnotenie IHV brankárov v majstrovských zápasoch v jesennej časti sezóny 2010/2011

- Vstupné expertízne hodnotenie IHV brankárov v majstrovských zápasoch v jesennej časti sezóny 2010/2011

\section{Výstupné hodnotenie (Dt1)}

Koniec HO II (Apríl 2011 - Jún 2011)

- Výstupné hodnotenie IHV brankárov v majstrovských zápasoch v jarnej časti sezóny 2010/2011

- Výstupné expertízne hodnotenie IHV brankárov v majstrovských zápasoch v jarnej časti sezóny 2010/2011

\section{VÝSLEDKY PRÁCE}

POROVNANIE TRÉNINGOVÝCH UKAZOVATELOV

EXPERIMENTÁLNEHO A KONTROLNÉHO SÚBORU

Obrázok 3 - Porovnanie experimentálneho a kontrolného tréningového programu brankára (min)

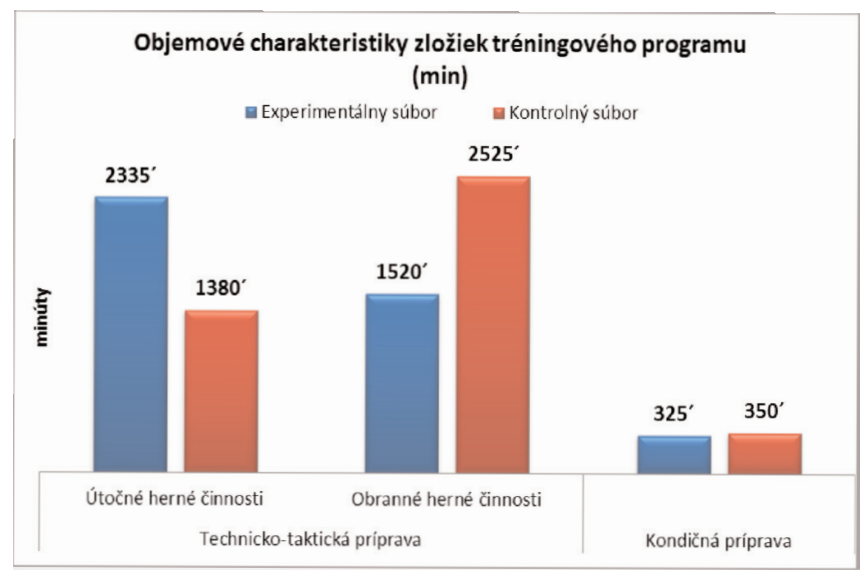

$\mathrm{Na}$ obrázku 3 prezentujeme rozdiely $\mathrm{v}$ objemoch ( $\mathrm{v}$ min.) zamerania tréningových programov experimentálneho a kontrolného súboru z hl'adiska kondičnej prípravy a technicko-taktickej prípravy (obranné a útočné herné činnosti).

V nasledujúcom obrázku 4 uvádzame porovnanie tréningového zat’aženia z hl'adiska objemu (v min.) experimentálneho súboru so zameraním na útočné herné činnosti s tradičným tréningovým programom so zameraním na obranné herné činnosti.

Proporcionalita technicko-taktickej a kondičnej prípravy bola podstatou našej práce $\mathrm{s}$ brankármi. S experimentálnym súborom sme sa zamerali na nácvik a zdokonal'ovanie rôznych parametrov útočných herných činností najčastejšie využívaných v zápase. Najväčší rozdiel v objeme (v min.) medzi programom kontrolného a experimentálneho súboru bol v najčastejšie využívaných herných činnostiach v útočnej tak i v obrannej fáze hry. HČ nohou sa brankári experimentálneho súboru venovali o 725 minút viac ako kontrolný súbor. Tradičná príprava brankára naopak vychádza z dokonalej prípravy brankára z hl'adiska kvality obranných herných činností, preto sa brankári kontrolného súboru tejto časti TP venovali 1640 minút, čo predstavovalo o 635 minút 
viac ako experimentálny súbor. V objemovej charakteristike ostatných obranných a útočných herných činností nebol podstatný rozdiel medzi experimentálnym a kontrolným programom.

Kondičná príprava (nešpecifický tréningový podnet) mala rovnaké zameranie a objem v rámci tréningového programu experimentálneho tak aj kontrolného súboru.

Obrázok 4 - Proporcionalita technicko-taktickej a kondičnej prípravy experimentálneho a kontrolného súboru (min)

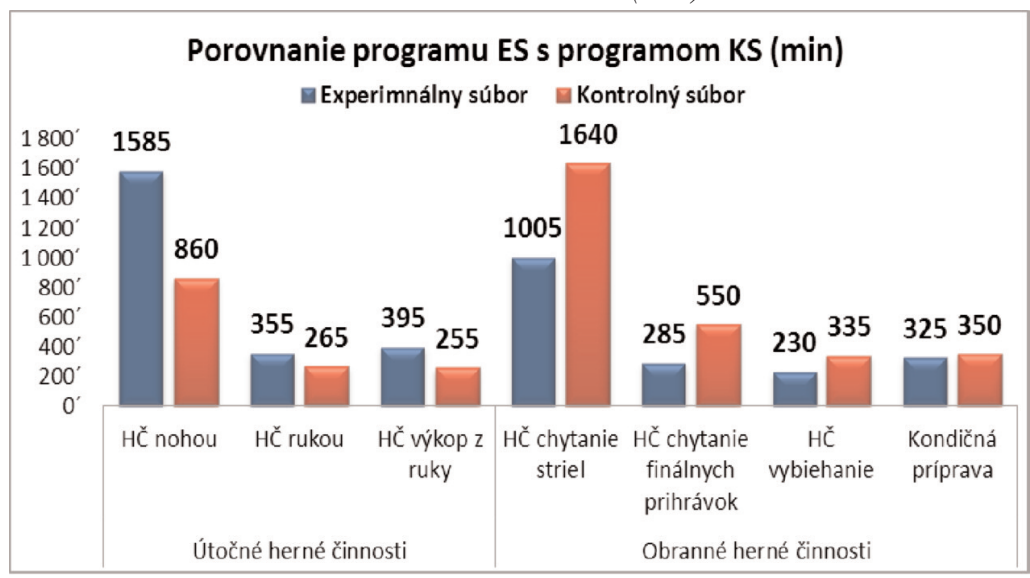

\section{VYHODNOTENIE INDIVIDUÁLNEHO HERNÉHO VÝKONU BRANKÁROV V ZÁPASE}

\section{Vybrané útočné herné činnosti brankárov experimentálneho a kontrolného súboru (ÚHČ) v zápase}

Brankári ES sa po experimentálnom tréningovom programe výrazne zlepšili v HČ nohou, spolu vykonali o 43 HČ viac a zároveň o 2 neúspešné HČ menej ako pred tréningovým programom. Počet neúspešných HČ nohou brankárov ES po experimentálnom tréningovom programe klesol o 2 herné činnosti, skôr ale môžeme povedat', že ostali na rovnakej úrovni, pretože tento rozdiel je minimálny pri porovnaní 36-tich zápasov. Počet neúspešných HČ výkop z ruky po experimentálnom tréningovom programe klesol o 10 HČ, naopak počet úspešných HČ stúpol o 7 (obrázok 5).

Obrázok 5 - vybrané ÚHČ brankára ES pred a po experimentálnom tréningovom programe (1)

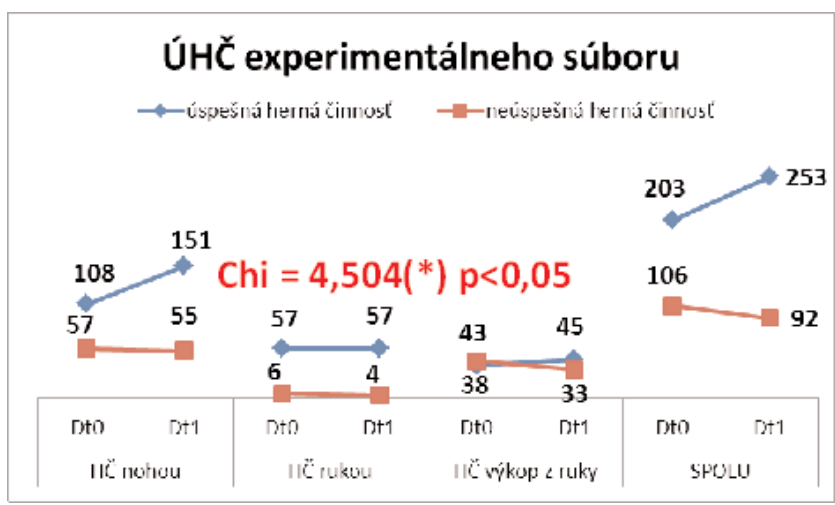

Vo vybraných útočných herných činnostiach brankára sme zaznamenali štatistické zlepšenie medzi útočnými hernými činnost’ami $\mathrm{v}$ zápase pred a po experimentálnom tréningovom programe $(\mathrm{p}<0,05)$. V ES došlo k zlepšeniu u všetkých hráčov súboru.

Spolu ES po experimentálnom tréningovom programe zaznamenal o 50 úspešných útočných herných činností viac a zároveň o 14 neúspešných útočných herných činností menej ako pred experimentálnym tréningovým programom. Pri porovnaní brankárov ES s juniorskými brankármi účastníkov ME 2010 (Peráček, Hrnčiarik 2010), po experimentálnom programe bola ich úspešnost' ÚHČ na priemernej úrovni juniorských brankárov ME 2010, čo je pre brankárov druhej dorasteneckej ligy vel'mi dobrý výsledok.

Brankári KS po kontrolnom programe zaznamenali vyšší počet úspešných ÚHČ iba v HČ noho a to o 12 HČ. Zároveň zaznamenali aj o 10 menej neúspešných HČ nohou. V ÚHČ rukou po kontrolnom programe 
brankári KS zaznamenali približne rovnaký počet úspešných ale zároveň o 7 neúspešných HČ viac, čo je výrazne menej v porovnaní s ES. V ÚHČ výkop z ruky brankári KS zaznamenali približne rovnaký počet úspešných aj neúspešných HČ brankára pred aj po kontrolnom programe. Brankári KS zaznamenali po kontrolnom programe o 10 úspešných ÚHČ viac pri zachovanom počte neúspešných ÚHČ (obrázok 6).

Obrázok 6 - vybrané ÚHČ brankára KS pred a po kontrolnom tréningovom programe (1)

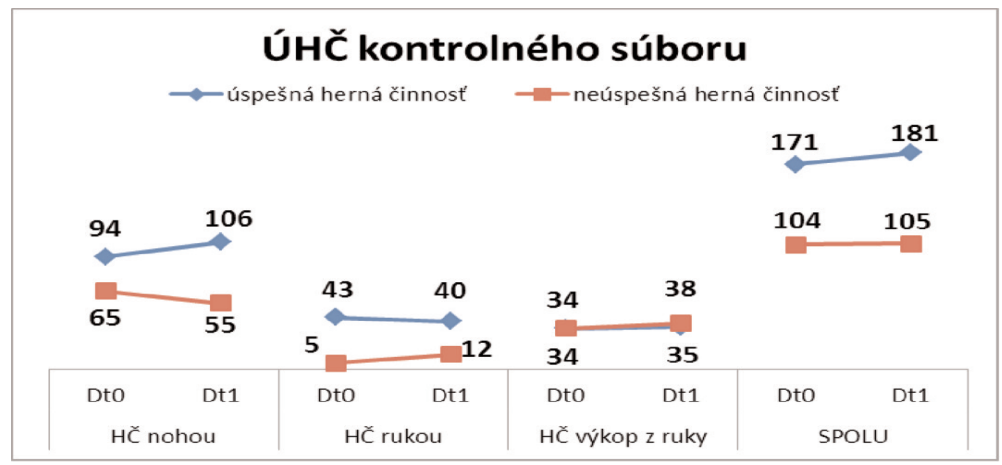

Po experimentálnom a kontrolnom tréningovom programe brankára, sme zaznamenali štatistickú významnost' rozdielu individuálnych herných výkonov $\mathrm{v}$ útočných herných činnostiach medzi brankármi ES a KS (obrázok 7). Brankári ES vykonali o 59 ÚHČ viac ako brankári KS za rovnaký počet zápasov. Úspešnost’ týchto činností u experimentálneho súboru bola na úrovni $73,3 \%$, čo predstavovalo o $10 \%$ vyššiu úspešnost' ako u kontrolnéh o súboru.

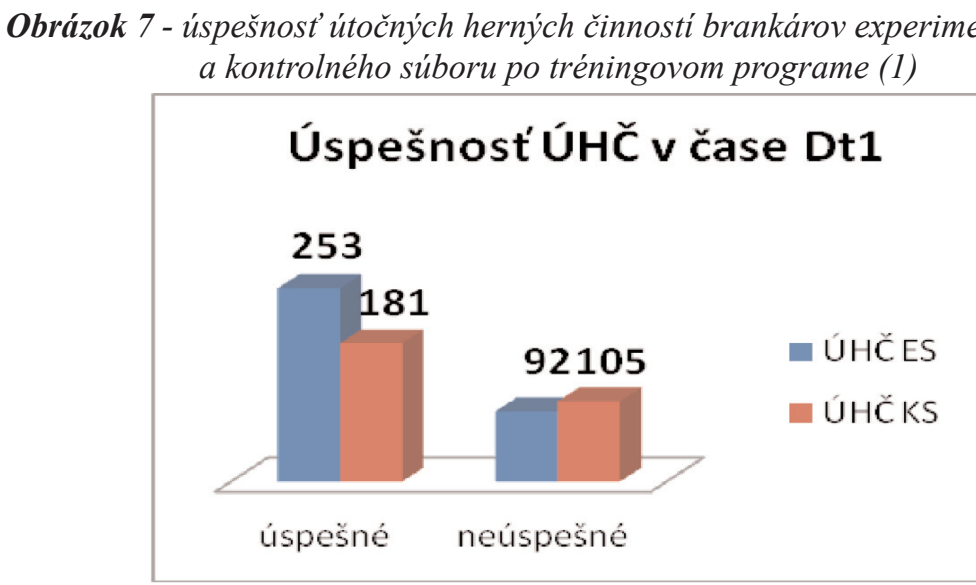

Vybrané obranné herné činnosti brankárov experimentálneho a kontrolného súboru (OHČ) v zápase

Nezaznamenali sme štatistickú významnost' rozdielov úspešnosti u brankárov ES aj KS medzi úspešnost'ou OHČ pred a po tréningovom programe. Na základe týchto výsledkov môžeme teda povedat', že IHV brankárov ES v OHČ sa po experimentálnom tréningovom programe nezmenil, teda ani nezhoršil. Úspešné aj neúspešne

Obrázok 8 - vybrané obranné herné činnosti brankárov ES a KS pred a po tréningovom programe (1)

\section{OHČ experimentálneho súboru}

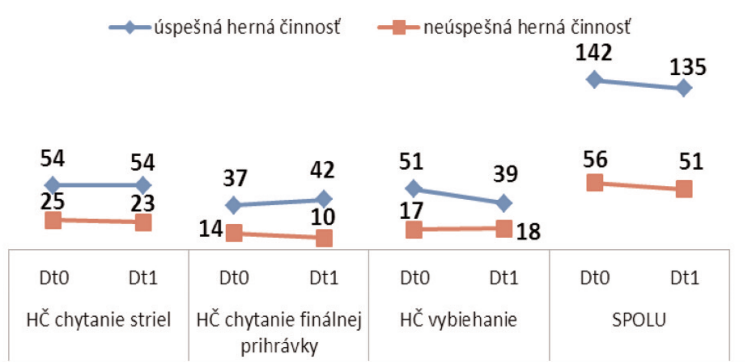

\section{OHČ kontrolného súboru}
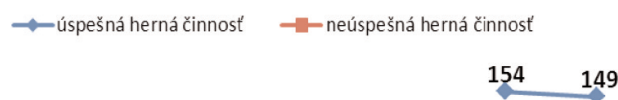

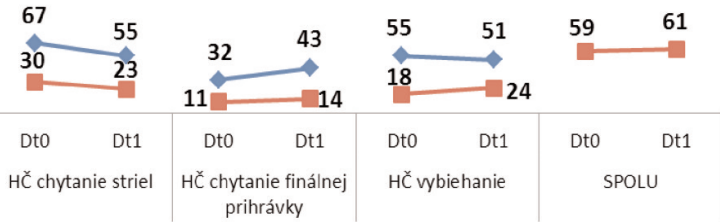


OHČ v sledovaných zápasoch po tréningovom programe boli na podobnej úrovni ako v zápasoch pred tréningovým programom (obrázok 8). Tak ako u ES, aj brankári KS zaznamenali takmer identický počet úspešných aj neúspešných OHČ pred a po tréningovom programe.

Brankári KS zaznamenali pred experimentom (Dt0) o 15 obranných herných činností viac ako brankári ES. Najväčší rozdiel sme zaznamenali v HČ chytanie striel (obrázok 9). Z hl’adiska porovnania úspešnosti brankári

Obrázok 9 - porovnanie obranných herných činností v zápase brankárov ES a KS pred a po tréningovom programe (1)

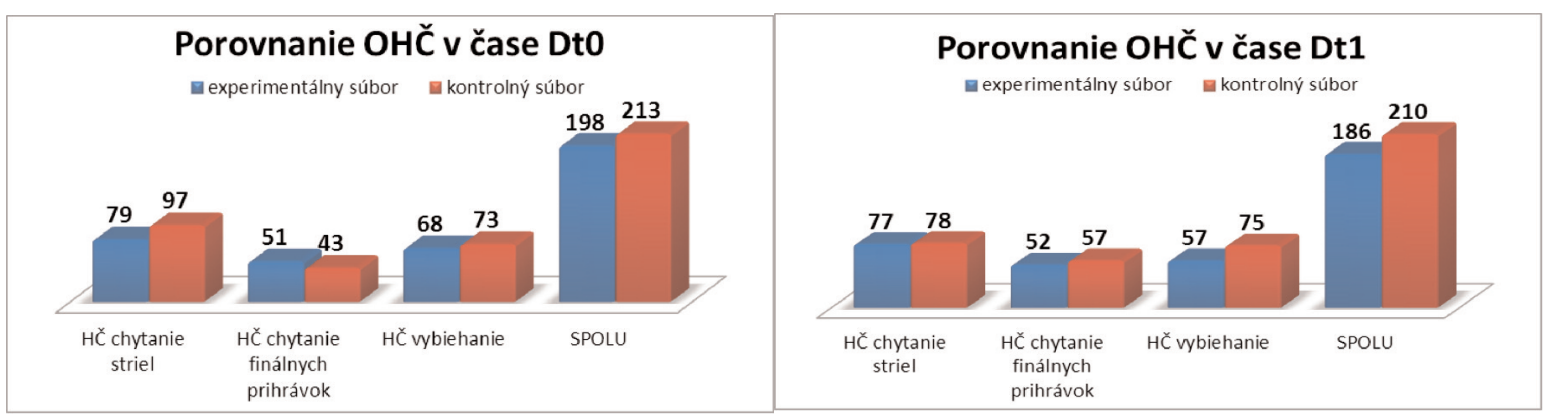

ES a KS zaznamenali vel'mi podobnú úroveň $(71,7 \%$ - 72,3\%). Pred experimentom sme nezaznamenali štatisticky významný rozdiel medzi IHV brankárov KS a ES v OHČ v sledovaných zápasoch $($ Chi = 0,017).

Po kontrolnom tréningovom programe brankári KS zaznamenali podobný počet OHČ ako pred týmto programom. V porovnaní s brankármi ES, aj po tréningovom programe vykonali vyšší počet OHČ (o 24 HČ) s úspešnost'ou $71 \%$. Z hl'adiska porovnania úspešnosti po tréningovom programe vyššiu úspešnost' zaznamenali brankári ES 72,6\% - KS 71\%. Najväčší rozdiel v počte HČ medzi ES a KS sme po tréningovom programe zaznamenali v HČ vybiehanie proti lopte, brankári KS realizovali o 18 HČ viac ako brankári ES. Po tréningovom programe sme nezaznamenali štatisticky významný rozdiel medzi herným výkonom brankárov KS a ES v OHČ v sledovaných zápasoch $(\mathrm{Chi}=0,129)$.

\section{EXPERTÍZNE HODNOTENIE IHV BRANKÁROV}

Aby sme dokázali, že hodnotenie expertov je nezávislé, vypočítali sme na základe ich výsledkov hodnotenia jednotlivých brankárov pred a po pedagogickom experimente Kendallow koeficient zhody (W), z ktorého sme následne vypočítali Chi kvadrát (Chi).

Tabul'ka 1 - Kendallow koeficient (W) a chi kvadrát (Chi) v čase Dt0 a Dt1

\begin{tabular}{|c|c|c|c|c|c|}
\hline ES & $\begin{array}{c}\text { Pred } \\
\text { experimentom } \\
\text { (Dt0) }\end{array}$ & $\begin{array}{c}\text { Po } \\
\text { experimente } \\
\text { (Dt1) }\end{array}$ & KS & $\begin{array}{c}\text { Pred } \\
\text { experimentom } \\
\text { (Dt0) }\end{array}$ & $\begin{array}{c}\text { Po } \\
\text { experimente } \\
\text { (Dt1) }\end{array}$ \\
\hline \multirow{2}{*}{ ES 1} & $W=0,005$ & $W=0,0207$ & \multirow{2}{*}{ KS 1} & $W=0,0052$ & $W=0,0054$ \\
\hline & Chi $=0,150$ & Chi $=0,621$ & & Chi $=0,155$ & Chi $=0,162$ \\
\hline \multirow{2}{*}{ ES 2} & $W=0,0099$ & $W=0,0121$ & \multirow{2}{*}{ KS 2} & $W=0,0117$ & $W=0,018$ \\
\hline & Chi $=0,296$ & Chi $=0,364$ & & Chi $=0,352$ & Chi $=0,539$ \\
\hline \multirow{2}{*}{ ES 3} & $W=0,0086$ & $W=0,004$ & \multirow{2}{*}{ KS 3} & $W=0,0287$ & $W=0,0292$ \\
\hline & Chi $=0,258$ & Chi $=0,121$ & & Chi $=0,862$ & Chi $=0,877$ \\
\hline \multirow{2}{*}{$\begin{array}{c}\text { ES } \\
\text { SPOLU }\end{array}$} & $W=0,02$ & $W=0,0389$ & \multirow{2}{*}{$\begin{array}{c}\text { KS } \\
\text { SPOLU }\end{array}$} & $W=0,0427$ & $W=0,0423$ \\
\hline & Chi $=0,599$ & Chi $=1,167$ & & Chi $=1,281$ & Chi $=1,268$ \\
\hline
\end{tabular}

V tabul'ke 1 uvádzame výsledky Kendallowho koeficientu zhody a Chi kvadrátu experimentálneho a kontrolného súboru pred a po tréningovom programe.

Chi kvadrát z Kendallowho koeficientu zhody pri žiadnom brankárovi, ani v súčte hodnotení experimentálneho a kontrolného súboru, nebol štatisticky významný. Výsledky nám ukázali, že hodnotenie expertov bolo objektívne a ich hodnotenia sa štatisticky významne nelíšili. 


\section{POROVNANIE A ŠTATISTICKÉ VYHODNOTENIE EXPERTÍZNEHO HODNOTENIA IHV BRANKÁROV EXPERIMENTÁLNEHO A KONTROLNÉHO SÚBORU}

Expertízne hodnotenie IHV brankára experimentálneho súboru M.D.

Celkový priemer hodnotenia $\mathrm{v}$ čase Dt0 bol 3,03. Experti hodnotili brankára 23 krát škálou „3“, škálou „2“ a „,4“ 6 a 7 krát.

Tabul'ka 2 - expertízne hodnotenie brankára ES M.D. v čase Dt0 a Dt1

\begin{tabular}{|c|c|c|c|c|c|c|c|}
\hline \multicolumn{4}{|c|}{ Pred tréningovým programom (Dt0) } & \multicolumn{4}{|c|}{ Po tréningovom programe (Dt1) } \\
\hline Zápas č. & prieme & కkála & poket & Zápas č. & priemen & కkála & pox̌et \\
\hline 1 & 3,17 & "1" & 0 & 1 & 2,33 & ${ }^{n} 1^{n}$ & 3 \\
\hline 2 & 2,50 & "2n & 6 & 2 & 2,67 & "2" & 17 \\
\hline 3 & 3,17 & "3n & 23 & 3 & 1,67 & "3n" & 14 \\
\hline 4 & 3,00 & "4" & 7 & 4 & 3,17 & ${ }^{4} 4^{1}$ & 2 \\
\hline 5 & 3,33 & "5n & 0 & 5 & 1,83 & ${ }^{5} 5^{n}$ & 0 \\
\hline 6 & 3,00 & spolu & 36 & 6 & 2,83 & spolu & 36 \\
\hline \multicolumn{2}{|l|}{ Priemer } & & & Priemer & 2,42 & & \\
\hline
\end{tabular}

Po tréningovom programe experti hodnotili brankára najčastejšie škálou „2“ - 17 krát, túto škálu experti využili o 11 krát viac ako pred tréningovým programom. Škálou „1“ brankára hodnotili 3 krát. Priemer hodnotiacich škál bol 2,42, čiže hodnotenie brankára po tréningovom programe bolo v priemere na zápas o 0,61 škály lepšie.

\section{Experimentálny súbor brankárov}

Pomocou párového T-testu sme zistili vysokú štatistickú významnost' rozdielov medzi hodnoteniami expertov pred a po experimentálnom tréningovom programe na hladine významnosti $\mathbf{p}<\mathbf{0 , 0 1}$. Štatistika nám teda potvrdila významné zlepšenie úrovne IHV brankárov experimentálneho súboru v majstrovských zápasoch po experimentálnom tréningovom programe (Dt1).

Obrázok 10-Expertízne hodnotenie brankárov ES v čase Dt0 a Dt1

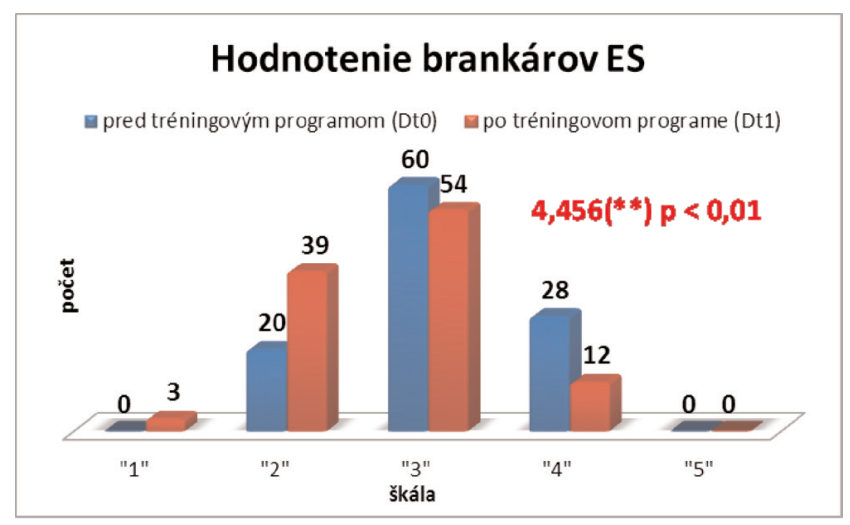

Škálou „2“ (brankár chytal vel’mi dobre) experti hodnotili brankárov ES po TP (Dt1) o 19 krát viac ako pred TP (Dt0) - spolu 39 krát. Naopak škálou „4“ (brankár chytal zle) experti hodnotili brankárov ES po TP (Dt1) o 16 krát menej ako pred TP (Dt0) - spolu 12 krát. V rozhovoroch po zápasoch v čase Dt1, experti vyslovili spokojnost' s výkonnost'ou brankárov ES v sledovaných zápasoch. Výrazne poklesol počet zápasov, v ktorých brankári nesprávne vyriešili kritickú hernú situáciu a ovplyvnili tým výsledok zápasu. Útočné herné činnosti, ktoré v zápase brankári použili boli vo väčšine prípadov takticky správne vybrané a technicky správne vykonané. 


\section{Kontrolný súbor brankárov}

Pomocou párového T-testu sme zistili štatistickú významnost' rozdielov medzi hodnoteniami expertov pred a po kontrolnom tréningovom programe na hladine významnosti $\mathbf{p}<\mathbf{0 , 1 0}$. Štatistika nám ukázala zlepšenie úrovne IHV brankárov kontrolného súboru $\mathrm{v}$ majstrovských zápasoch po kontrolnom tréningovom programe (Dt1).

Obrázok 11 - Expertízne hodnotenie brankárov KS v čase Dt0 a Dt1

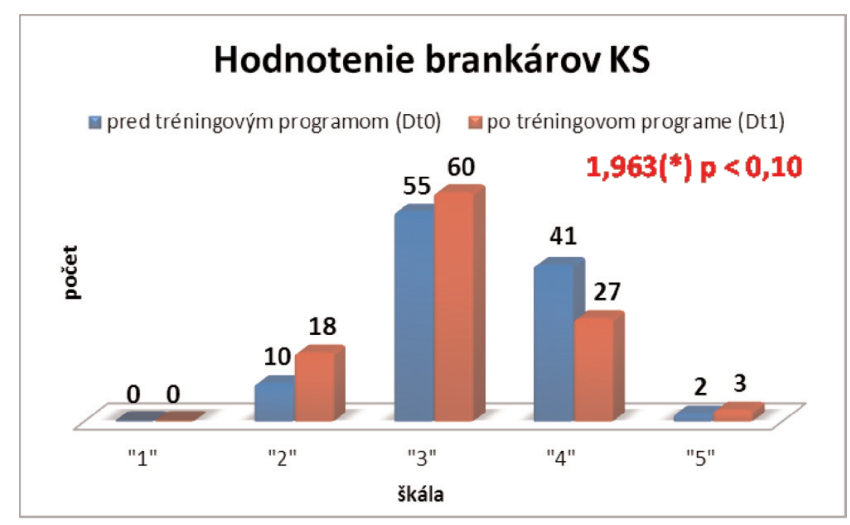

Škálou „3“ (brankár chytal dobre) experti hodnotili IHV brankárov KS po TP (Dt1) 60 krát, čiže len o 5 krát viac ako pred TP (Dt0). Najvýraznejší rozdiel v hodnotení sme zaznamenali pri poklese hodnotenia expertov škálou „4“ (brankár chytal zle), ktorou experti hodnotili IHV brankárov KS po TP (Dt1) o 14 krát menej ako pred TP (Dt0) - spolu 27 krát. Tak isto experti častejšie hodnotili brankárov KS po tréningovom programe (Dt1) škálou „2“( (brankár chytal vel'mi dobre).

V rozhovoroch po zápasoch v čase Dt1, experti potvrdili zlepšenie IHV brankárov staršieho dorastu KS (J.C. a M.T.) v sledovaných zápasoch. HČ brankára, ktoré využívali v majstrovských zápasoch boli viac krát takticky správne vybrané a technicky správne vykonané. Z hl’adiska OHČ brankári v kritických herných situáciách vykonali adekvátnu hernú činnost’ brankára so správnym technickým vykonaním. Kvalita IHV brankára mladšieho dorastu M.H. pred, aj po tréningovom programe kolísala z hl'adiska hodnotenia tých parametrov expertmi, ktoré u brankára sledovali.

\section{Porovnanie experimentálneho a kontrolného súboru v čase Dt0}

Pred tréningovým programom experti najčastejšie hodnotili brankárov experimentálneho a kontrolného súboru škálou „3“. Rozdiel sme zaznamenali pri škále „2“ (brankár chytal vel’mi dobre) ktorou experti o 10 viac krát hodnotili ES a pri škále „4“ (brankár chytal zle) ktorou naopak o 13 viac krát hodnotili brankárov KS.

Obrázok 11 - Expertízne hodnotenie brankárov KS v čase Dt0 a Dt1

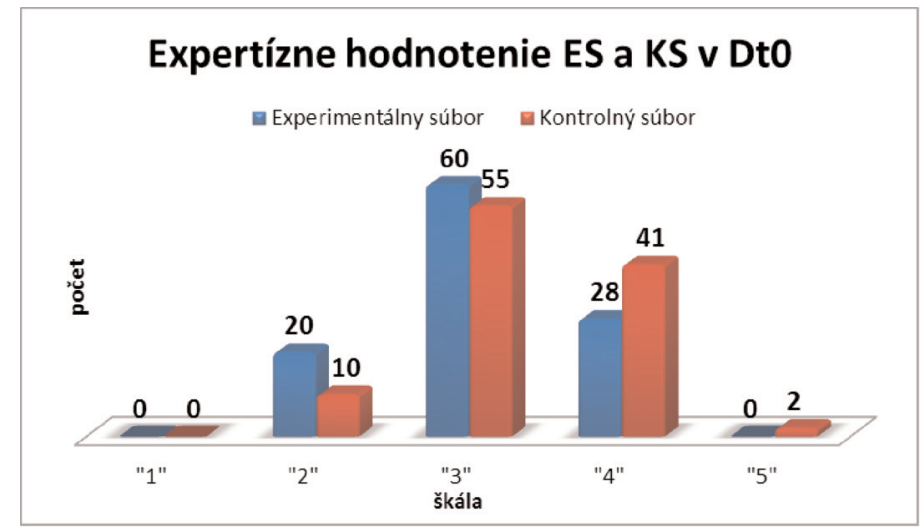




\section{Porovnanie experimentálneho a kontrolného súboru v čase Dt1}

Obrázok 13 - hodnotenie brankárov ES a KS v čase Dt1

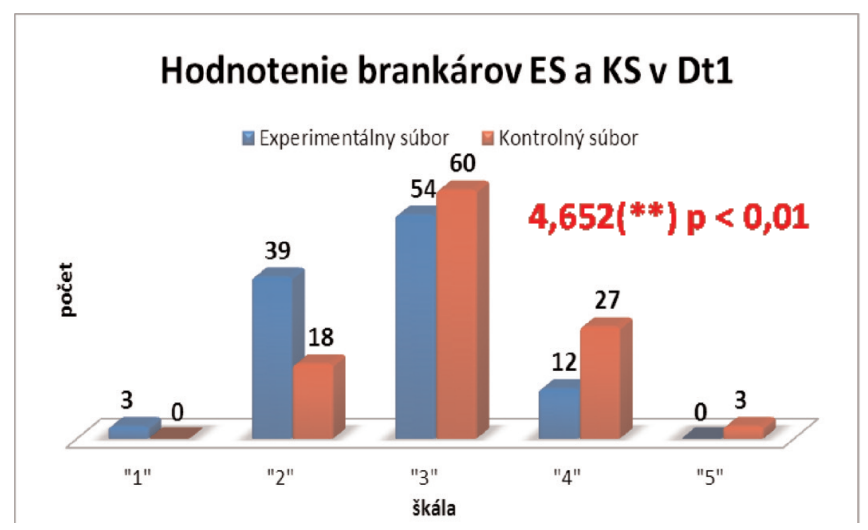

Po tréningovom programe experti opät’ najčastejšie brankárov ES aj KS hodnotili škálou „,3“ (brankár chytal dobre). Avšak experti brankárov ES hodnotili škálou „2“ o 21 krát častejšie ako brankárov KS.

Brankárov KS hodnotili experti o 15 krát viac škálou „4“ (brankár chytal zle). Pomocou párového T-testu sme zistili vysokú štatistickú významnost' rozdielov medzi hodnoteniami expertov experimentálneho a kontrolného súboru po tréningovom programe (Dt1) na hladine významnosti $p<0,01$. Na základe tohto faktu, môžeme povedat', že brankári ES sa výrazne zlepšili z hl'adiska porovnania hodnotenia expertov.

\section{DISKUSIA}

Futbal v súčasnej dobe ovplyvňuje viacero významných vývojových tendencií, jedna z nich je intenzifikáciu hry. Táto sa netýka iba vonkajšieho zat’aženia z bioenergetického hladiska, ale aj vonkajšieho zat'aženia z hl'adiska hernej aktivity. Ak chcú brankári často krát zrýchlit' hru, kladie to na nich enormné nároky. Ak má brankár malé skúsenosti, je neúspešnejší v útočných herných činnostiach. S problémom anticipácie a časového aspektu herných zručností sa zaoberali REEP - BENJAMIN (1968), WILLIAMS (1973), TOERING et al. (2009), WEINECK (1997) a COSTA - GARGANTA - GRECO - MESQUITA - SILVA (2010). Za empirický dôkaz existencie anticipácie považujú úspešnost' herných činností, kde sa lopta pohybuje vel'mi rýchlo. U menej skúsených brankárov (hráčov) je možné či už jednoduchým pozorovaním, alebo náročnejšími technológiami zistit' nedostatok anticipácie. Z rozdielu medzi menej a viacej skúseným brankárom vyvodzujú záver, že subjekt sa učí anticipovat'. Úspešný nácvik anticipácie vyžaduje vel'mi dobré zvládnutie pohybovej stránky herných činností, čo umožňuje hráčovi, a brankárovi zvlášt', predikovat' vlastný pohybový čas a vyštartovat' vo vhodnom okamihu. Sústredenie na organizáciu pohybovej odpovedi môže viest' k rýchlejšej reakcii než je koncentrácia na loptu. Podnet je trvalo prítomný. V praxi býva táto skutočnost' vyjadrovaná vetou: „skôr než chytíš loptu, mal by si vediet', čo s ňou urobíšs. Proporcionalita úspešných a neúspešných herných činností jednotlivca je iná v seniorskej kategórii (PERÁČEK - HRNČIARIK - KOSTOLANSKÝ, 2008; PERÁČEK - HRNČIARIK, 2010) a iná v juniorskej kategórii. Pre herné (pohybové) činnosti je charakteristická vysoká frekvencia zmien intenzity pohybovej aktivity. Vo futbale sa táto intenzita mení každých 3 - 10 sekúnd. (BANGSBO LINDQVIST, 1992; VERHEIJEN, 1998), u juniora je tento interval dlhší (VERHEIJEN, 1998; PERÁČEK, 2012)

Požiadavky na výkonnost’ brankárov sa zmenou pravidla o „malej domov“ rozšírili. Podiel brankára na útočnej fáze hry začína byt' zretel'nejší o čom svedčia údaje mnohých analýz IHV brankárov v rôznych zápasoch vrcholových podujatí (HONZ, 1997; VERHEIJEN, 1998; TARKOVIČ, 2000; KOSTOLANSKÝ, 2006; HRNČIARIK, 2009; PERÁČEK - HRNČIARIK, 2010). Snaha kontrolovat' hru je l'ahšie realizovatel'ná, ak brankár je dostatočne kvalitne pripravený hrat' nohou na krátku i dlhú vzdialenost'. Toto zistenie potvrdzuje trend vysokej participácie brankárov na komplexnom hernom výkone družstva. Brankári sú nútení podávat' výkony na stále vyššej úrovni, či už sa to týka kvality obranných ale hlavne útočných herných činností. A ak si uvedomíme neustále sa zvyšujúcu konkurenciu, vývojové tendencie vo futbale, stále rýchlejšie lopty, rôzne iné materiály (kopačky,...), tak musíme rátat' s tým, že sa nároky na brankárov budú neustále zvyšovat'. Aby však brankári mohli podávat' najlepšie výkony, musia prejst' počas dlhodobej športovej prípravy mládeže aj pravidelným špeciálnym brankárskym tréningom. 
Vo všeobecnosti môžeme konštatovat', že z hl'adiska vrcholovej výkonnosti by malo byt' hlavným ciel'om v mládežníckych kategóriách budovanie vysokej úrovne individuálneho herného výkonu, aby potom brankár dokázal rozhodujúcou mierou participovat’ na vrcholovom hernom výkone družstva v kategórii dospelých. Tréningový proces mladých brankárov by mal smerovat' najmä $\mathrm{k}$ vytvoreniu potrebných pohybových a technicko-taktických základov pre d’alší športový rast. Toto potvrdzuje aj PERÁČEK (2004/a), ktorý tvrdí, Že zaostávame v individuálnej technicko-taktickej kvalite, v rýchlosti (takmer vo všetkých prejavoch), čo ostro kontrastuje $\mathrm{s}$ vývojovými tendenciami $\mathrm{v}$ medzinárodnom mládežníckom futbale. Najväčšie nedostatky sú v tréningovom procese, $\mathrm{v}$ jeho obsahovej preferencii, $\mathrm{v}$ proporcionalite metód a didaktických foriem prípravy, ktorá nezodpovedá potrebám vývoja hry.

Podobne ako v kategórii dospelých, tak aj futbal v mládežníckych kategóriách zaznamenáva neustály dynamický rast výkonnosti hráčov. Najlepšie mládežnícke družstvá sa prezentujú dynamickým, tvorivým a aktívnym futbalom. Sledovanie vrcholových mládežníckych podujatí (ME “17“, ME “19“, MS “17“, MS “20“) naznačuje, že z pohl'adu vývojových tendencií musia byt' mladí hráči pripravovaní nielen na súčasnú úroveň, ale najmä na budúce požiadavky tejto hry, ktoré budú za niekol'ko rokov nesporne vyššie, náročnejšie (PERÁČEK, 2002). Preto v športovom tréningu vo futbale neustále rastie význam riadenia športovej prípravy, v ktorej sa uplatňujú nové vedecké poznatky (PERÁČEK, 1999). Úlohou trénera brankárov nad’alej zostáva, čo najlepšie pripravit' mladých brankárov $\mathrm{v}$ zmysle najnovších poznatkov, neustálych zmien pravidiel, s rešpektovaním všetkých požiadaviek, ktoré kladie súčasný vrcholový futbal zvlášt' na túto hráčsku funkciu. PERÁČEK (1996) d’alej tvrdí, že hl'adanie nových ciest v oblasti plánovania, organizácie a riadenia tréningového procesu je nevyhnutnou podmienkou zvyšovania efektívnosti tohto procesu. Rozširovanie poznatkov, ktoré rozhodujúcim spôsobom ovplyvňujú jednotlivé obsahové zameranie zložiek športového tréningu (kondičnú, technicko-taktickú, psychickú, ale aj teoretickú prípravu) a tiež aj súčastí tréningového procesu a didaktiku športového tréningu sú najdôležitejším vonkajším zdrojom d’alšieho rastu úrovne hry.

Aby sme dosiahli efektívnost' športovej prípravy je nutné neustále prehodnocovanie obsahu tréningových programov brankára, aby príprava rešpektovala vývojové tendencie. S manipulovaním proporcionality súčastí TP urobil pedagogický experiment v prirodzených podmienkach tréningového procesu aj ZÁHORSKÝ (2008) ktorý dokázal, že špecifické podnety v tréningovom procese výrazne ovplyvnia herný výkon v zápase. Na druhej strane toto vyžaduje kvalitné plánovanie tréningového procesu, ale HASPRÚN - ZÁHORSKÝ (2008) tvrdia, že v slovenskom mládežníckom futbale chýba kvalitné plánovanie a evidencia tréningového zat’aženia (nie je adekvátna spätná väzba).

Evidencia tréningovej činnosti je neodmyslitel'nou požiadavkou pre plánovaný a racionálny tréningový proces. Avšak tréningový program a hlavne reálny tréningový proces bez jeho evidencie stráca zmysel. V našej práci sme podrobne viedli evidenciu tréningového zat’aženia, ako základ pre získanie spätnej väzby a následnej korekcie tréningu s ciel'om zvyšovania trénovanosti a výkonnosti brankárov. Musíme zdôraznit', že nešlo len o deskriptívny kvantitatívny zápis zat’ažovania, ale predovšetkým o vyhodnotenie a prenos získaných poznatkov do tréningového procesu a zápasu (FAJFER, 2005).

Na evidenciu tréningového zat’aženia sme vo výskume použili záznamový hárok podl’a PERÁČKA (1993), ktorý rešpektuje periodizáciu ročného tréningového cyklu vo futbale (prípravné obdobie I, hlavné obdobie I, prechodné obdobie I a prípravné obdobie II, hlavné obdobie II, prechodné obdobie II). Registrujeme v ňom všeobecné a špeciálne tréningové ukazovatele. Na základe evidencie tréningového zat’aženia sme sa mohli vyjadrit' k všeobecným a špeciálnym tréningovým ukazovatel'om, a následne k proporcionalite útočných a obranných herných činností v rámci technicko-taktickej prípravy brankára.

Pri stanovení experimentálneho činitel'a sme vychádzali z našich viac ako 100 analýz herného výkonu najlepších juniorských a seniorských brankárov, v súčasnej dobe z požiadaviek hry seniorského brankára a z vývojových tendencií k tejto hráčskej funkcii. Vychádzajúc z poznatkov PERÁČKA (1992), domnievame sa, že pre úspešné uplatnenie sa brankára $\mathrm{v}$ zápase sú $\mathrm{v}$ dnešnom futbale rozhodujúce parametre útočných herných činností, ktoré predstavujú základ spolupráce $\mathrm{s}$ hráčmi v poli v zložitých herných situáciách. Táto naša úvaha pri koncipovaní experimentálneho činitel'a a realizácii pedagogického experimentu bola aj v súlade so SMITHOM (2005), ktorý tvrdí, že hráč by mal byt' vedený pri tréningu tak, aby úsilie trénera smerovalo k požiadavkám hry. Pokial' boli upravené pravidlá tak, ako ukazujú aj naše analýzy IHV brankárov (HRNČIARIK, 2009; PERÁČEK - HRNČIARIK, 2010), z hl'adiska frekvencie HČJ je v zápase vyšší počet útočných HČJ ako obranných HČJ. Tento záver z nášho predvýskumu bol impulzom na úpravu obsahového 
zamerania špecializovanej prípravy brankára. Navrhované úpravy v obsahu TP a koncipované cvičenia (plánovanie TP) podiel'ajúce sa na d’alšom riadení IHV sú konkrétne, špecifické a konzistentné s činnost’ou brankára v zápase, to znamená, že zapadajú do obsahu TP (herné činnosti učiaceho sa brankára) a pomáhajú ju pretvárat'. Tento postupný vývoj, ktorý sme realizovali v našom experimente v krátkych krokoch (v rámci TMC) nazval SMITH (1971) postupnou aproximáciou alebo postupnou metamorfózou zručností (ktorá bola ciel'om nášho experimentu). Jedna $\mathrm{z}$ dôležitých funkcií $\mathrm{v}$ takto koncipovanom experimente je sústredená pozornost' brankára na zlepšenie kvality útočných herných činností (ÚHČ) a na ich pridaní do obsahu TP. Tento prístup, v ktorom sa odráža - úplne - aj jedna zo zákonitostí tréningového procesu (ako špeciálneho výchovno-vzdelá vacieho procesu) - rozvíjajúci sa charakter tréningového procesu - nám umožní pochopit' a vysvetlit' vzt'ahy medzi mladým a vrcholovým hráčom a hlavne nám umožní odpovedat' na otázku, či sa má činnost’ v TP (a aj obsah TP) považovat' za model, alebo iba za určitý moment vývoja hráča (MARSENACH, 1969; SINGER, 1972; MARSENACH - DRUENNE, 1974). Učenie (tréning) a herný výkon musíme od seba odlišovat'. Existencia herného výkonu ešte neumožňuje tvrdit', že došlo k učeniu. Vo výsledkovej časti sme ukázali, že došlo k zmene kvality herného výkonu. Vplyvom rôznych faktorov a premenných sa však môže prejavovat' kolísanie herného výkonu, ale aj vzostup prípadne jeho pokles. Toto môže viest' k nepravdivým záverom o tréningu (učení). Dobre naučené herné zručnosti sú však vel'mi odolné voči vplyvu týchto podmienok. Adekvátne krytie je v súlade s teóriou identických prvkov (SINGER, 1972) podl’a ktorej čím sú dve herné situácie v nácviku (tréningovom procese) a v zápase podobnejšie, tým viac transferu môžeme očakávat'. Experimentálny program brankára je charakterizovaný trendom uplatňovania situačnej didaktiky a teórie adekvátneho krytia, aby formovanie a rast herného výkonu prebiehali $\mathrm{v}$ prevažnej miere práve $\mathrm{v}$ podmienkach identických so štruktúrou pohybu hráča $\mathrm{v}$ zápase a rešpektovali motorické učenie. Takýto prístup nám umožnil plánovat' taký obsah TP, kedy sa musia rozhodovat’ brankári pod časovým tlakom. Ďalej bolo možné v tréningovom procese zvýraznit' zámerné kondičné zat’ažovanie (vytvárat',prostredie“ druhého polčasu, záveru zápasu). Týmto sa dala do určitej miery prenášat' do tréningového procesu jedinečná funkcia stretnutia spojená so stálou neistotou, rizikom a situačne špecifickými požiadavkami na okamžitý úspech pri riešení herných situácií. Takto sa mení chápanie tréningovej činnosti ako určitého skúšobného konania bez rizika.

Myslíme si, že už v tejto etape športovej prípravy mládeže vo futbale je potrebné venovat' sa rozvoju pohybových schopností a herných zručností v podmienkach pravidelného individuálneho tréningu. Brankári by si mali osvojit' technickú stránku obranných a útočných herných činností v žiackych kategóriách a v dorasteneckých kategóriách by sa mali venovat' ich zdokonal'ovaniu v podmienkach, ktoré sú charakteristické väčším časovým a priestorovým tlakom (zápasové podmienky) a pod vplyvom únavy. Brankári by sa mali postupne naučit' opakovane riešit' zložité herné situácie aj v stave únavy (DOBRÝ - SEMIGINOVSKÝ, 1986).

Rast výkonnosti hráča je v podstate procesom adaptácie, procesom morfologickej a funkčnej prestavby organizmu hráča $\mathrm{v}$ zmysle prispôsobenia sa požiadavkám daného športového výkonu. Tieto požiadavky musia byt' kvantifikované pokial' možno čo najpresnejšie, čo umožňuje exaktné porovnanie zadaných požiadaviek so skutočne vykonanou tréningovou prácou za účelom zlepšenia výkonu. Iba týmto spôsobom je možné posúdit' efektivitu tréningového procesu a iba takto sa môžu akceptovat' dôležité modifikácie a získané poznatky o tréningovom zat’ažení (PERÁČEK, 1996). Preto sú aj viaceré súčasné výskumy zamerané na hladanie modelu zat’aženia hráča v rôznych vekových kategóriách vo futbale (PERÁČEK, 2002).

Požiadavky na výkon hráča, predovšetkým vrcholového futbalu, sa neustále zvyšujú (MORTON - COURT, 2002; KRUSTRUP - MOHR - ELLINGSGAARD - BANGSBO, 2005; ROXBOURG, 2006; PERÁC̆EK, 2004b). V záujme zabezpečenia racionálneho ovplyvňovania výkonnosti hráčov, je nutné odborne s objektívnym posúdením riadit' tréningový proces. To bol jeden z dôvodov, prečo sme sa v tréningovom procese pokúsili objektívne hodnotit' zat’ažovanie brankárov kategórii staršieho dorastu.

Myslíme si, že rast výkonnosti brankára závisí predovšetkým od účinnosti športového tréningu, od jeho riadenia, ktoré prebieha na rôznych úrovniach. Pre efektívne riadenie športového tréningu treba poznat' zákonitosti rastu športovej výkonnosti.

Všetky tréningové podnety experimentálneho súboru vychádzali z požiadaviek na brankára vrcholovej úrovne ich vekovej kategórie. Počas tréningov sme s brankármi vel’a komunikovali a vysvetl'ovali im zameranie a zmysel individuálnych tréningových jednotiek brankára, aby sami pochopili ich význam. Predpokladali sme tým nárast záujmu brankárov o problematiku zat’ažovania vo vrcholovom futbale a tým aj možnost' zabezpečenia kladného tréningového efektu.

Na herný výkon brankára vo futbale vplýva vel’a ukazovatel'ov, ktoré ho ovplyvňujú a modifikujú. Zápas 
je jedinou oblast'ou, kde dochádza k overeniu vytváranej odolnosti herného výkonu (THISSEN, 2001). Rozhodujúcim kritériom pre výkon hráča vo futbale je teda jeho výkon v zápase. Pre brankára toto konštatovanie platí ešte výraznejšie, pretože každá jeho chyba, či technický nedostatok často krát môže rozhodnút' o konečnom výsledku zápasu. Pri hodnotení herného výkonu sme sa snažili o identifikáciu tých ukazovatel'ov, ktoré v dostatočnej miere objektivizujú aktuálny stav herného výkonu sledovaného jedinca (TARKOVIČ - LIPKA, 1998; PAKUSZA, 2005) v našom prípade brankára.

Za účinný tréningový program považujeme taký program, ktorého obsah a dávkovanie, vyvoláva väčší efekt v rozvoji hernej výkonnosti ako tradičné tréningové programy a zároveň nespôsobuje narušenie zdravotného stavu športovca (REILLY, 2001). Ak sme toto zvolili za premisiu, tak môžeme povedat', že nami navrhnutý tréningový program s preferovaním útočných herných činností brankára bol účinný.

\section{ZÁVERY}

Podstata nášho tréningového programu vychádzala zo súčasných pravidiel futbalu a z požiadaviek a nárokov futbalového zápasu na brankára.

Terénne experimentálne a evaluačné vyšetrovanie vykonávané v tréningovom procese sledovaných brankárov ukázalo, že aplikácia tohto typu tréningového programu môže viest' k zvýšeniu výkonovej kapacity brankárov. Tieto výkonové efekty sa môžu u trénovaných jedincov objavit’ za 5-6 mesiacov zámernej aplikácie uvádzaného tréningového programu pri frekvencii tréningových jednotiek 2-krát týždenne po 70 - 90 minút (v závislosti od zamerania tréningu). Pri objeme $41 \%$ celkovej doby tréningu porovnaním výsledkov nášho výskumu obidvoch súborov sa ukázalo, že pokial' zvýšime zastúpenie útočných herných činností brankára (objem), zvýšime aj úroveň (kvalitu) týchto herných činností jednotlivca bez toho, aby sa znížila úroveň (kvalita) obranných herných činností jednotlivca.

Výskumy ukázali, že sa zvýšila početnost' útočných herných činností brankára na úkor obranných herných činností, čo súvisí so zmenou pravidiel futbalu v tejto oblasti za posledné obdobie. Brankár dnes nie je iba hráčska funkcia v ktorej dominuje chytanie resp. vyrážanie lopty. Brankár je dnes hráčska funkcia, ktorá musí ovládat” okrem „svojich“ herných činností, aj herné činnosti hráča v poli.

Stanovisko k hypotézam.

V práci sme potvrdili našu hlavnú hypotézu, že tréningový program juniorských brankárov s akcentom na útočné herné činnosti mal štatisticky významný vplyv na vybrané ukazovatele individuálneho herného výkonu experimentálneho súboru v zápase.

Potvrdili sa aj čiastkové hypotézy nášho výskumu.

Došlo k štatisticky významnému zlepšeniu experimentálneho súboru v útočných herných činnostiach brankára v zápase po absolvovaní tréningového programu.

Potvrdili sme, že experimentálny činitel', v ktorom sme akcentovali útočné herné činnosti nebude mat' štatisticky významný vplyv na obranné herné činnosti brankárov experimentálneho súboru v zápase po tréningovom programe.

Takisto sa potvrdilo, že štatistické významné zlepšenie experimentálneho súboru oproti kontrolnému súboru v hodnotení úrovne vybraných charakteristík IHV v zápase po tréningovom programe.

Potvrdili sme, že experimentálny súbor bude v porovnaní s kontrolným súborom štatisticky úspešnejší v expertíznom hodnotení individuálneho herného výkonu v sledovaných zápasoch po tréningovom programe.

Pre tréningovú prax vo futbale sú to významné nové poznatky o vybraných charakteristikách vonkajšieho zat'aženia brankára v kategórii dorastu z hl'adiska proporcionality útočných a obranných herných činností v komparácii s brankármi seniorskej kategórie.

Terénne výskumné šetrenia okrem hlavných poznatkov ukázali, že tréningový program experimentálneho súboru bol realizovatel’ný v praxi a prináša, aj d’alšie informácie pre budúci výskum a odkazy pre tréningovú prax.

- Tréningový program experimentálneho súboru s akcentom na útočné herné činnosti brankára pozitívne ovplyvnil ich výkonnost' v tejto oblasti.

- Potvrdili sme poznatok, že preferovaním špecifických podnetov môžeme zabezpečit' významné zlepšenie úrovne individuálneho herné výkonu brankára vo futbale 
Výsledky výskumu ukázali, že tréningový program s dominantným postavením útočných herných činností jednotlivca, ktorý vychádzal z vývojových tendencií v tejto oblasti zlepšil komplexný herný výkon brankára.

\section{LITERATÚRA}

BENČO, J. 2001. Metodológia vedeckého výskumu. Bratislava: IRIS, 2001. 194 s. ISBN 80-89018-27-0

BRÜEGGEMANN, D. 2008. Soccer alive - The game is the best teacher. London: Meyer \& Meyer Sport, 2008. 192s. ISBN 978-1-84126-235-2

BANGSBO, J. - LINDQUIST,F. 1992. Comparation of various exercise tests with endurance performance during soccer in profesional players. Jnt.J.Sports med. 1992, vol. 13, s.125 - 132.

COSTA, I. - GARGANTA, J. - GRECO, P. - MESQUITA, I. - SILVA, B. 2010. Analysis of Tactical Performance of Youth Soccer Players. New York : Sciences, 2010. s. 70-72.

DESHORS, M. 1997. Futbal: Pravidlá. Technika. Tréning. Galéria slávnych. Bratislava : Mladé letá, 1997. 151 s. ISBN 80-06-00773-X

DOBRÝ, L - SEMIGINOVSKÝ, B. 1988. Sportovni hry - výkon a trénink. 1. vyd. Praha: Olympia, 1988, 197 s. ISBN neuvedeno

DOVALIL, L. et al. 2002. Výkon a tréning ve sportu. Praha : Olympia, 2002. $331 \mathrm{~s}$

EJEM, M. 1970. Pokus o charakteristiku některých postupů hodnocení výkonu hráče v utkání sportovních her. In: Teorie a praxe tělesné výchovy, roč. 18, 1970, č. 7.

FAJFER, Z. et al. 1987. Príspěvek k problematice současního pojeti kondiční př́pravy hráče vrcholového fotbalu. Metodický list. Bratislava : Šport, 1987. $83 \mathrm{~s}$.

GAVORA, P. 1998. Systém analýzy správania sa učitel’a a žiaka In: ŠVEC, Š. et al. 1998. Metodológia vied o výchove. Bratislava: IRIS, 1998. 303s. ISBN 80-7178-367

HALZEWOOD, N. 1998. In the way goalkeepers. Edinburg : Mainstream, 1998. 89s. ISBN 80-329-902-4

HASPRÚN, M. - ZÁHORSKÝ, J. 2008. Výsledky auditu útvarov talentovanej mládeže za rok 2008. Záverečná správa predložená na VV SFZ. Bratislava, Marec 2008. Rukopis.

HOHMANN, A. - BRACK, R. 1983. Theoretische Aspekte der Leistungsdiagnistik im Sportspiel. In Leistungsport. č.3. Aachen : Edition Sport und Wessenschaft. 1983.

HONZ, O. 1997. Analýza herného výkonu brankára: diplomová práca. Bratislava: Fakulta telesnej výchovy a Športu Univerzity Komenského, 1997. 70 s.

HRNČIARIK, P. 2009. Analýza herného výkonu vybraných brankárov na ME 2008: diplomová práca. Bratislava: Fakulta telesnej výchovy a Športu Univerzity Komenského, 2009. 80 s.

KAČÁNI, L. 1991. Teória a didaktika športovej špecializácie - futbal. Učebné texty FTVŠ UK. Bratislava : UK, 1991. $116 \mathrm{~s}$.

KAČÁNI, L. 2000. Futbal. Teória a prax hernej pripravy. Bratislava : SPN, 2000. 143 s. ISBN 80-08-03164-6 KAČÁNI, L. - PERÁČEK, P. 1989. Aktuálne problémy hernej prípravy futbalistov. Bratislava: SÚV ČSZTV, 1989. $161 \mathrm{~s}$.

KORČEK, V. 2004. Úvod do metodológie športovej edukológie. Bratislava: STU, 2004. 87 s. ISBN 80-227-2170-0

KORČEK, F. - LUKNÁR, V. 1987. Futbal. Učebnica pre školenie trénerov. Bratislava : Šport, 1987. 298 s.

KORMANÍK, M. 2006. Využití počítačové techniky v tréninkovém procesu. In: Fotbal a trénink. č.2. Praha : ÚČFT, 2006. s. $24-26$.

KOSTOLANSKÝ, A. 2006. Analýza herného výkonu brankára: diplomová práca. Bratislava: Fakulta telesnej výchovy a Športu Univerzity Komenského, 2006. 104 s.

KRUSTUP, P. - MOHR, M. - ELLINGSGAARD, H. - BANGSBO, J. 2005. Physical demands during an elite female soccer game: Importance of training status. In: Medicine and Science in Sports and Exercise, 37, 2005. $1242-1248$.

MARSENACH, J. 1969. Jeux sportifs collectifs contribution a L'évolution de éducation physique.Paris : Revue EPS, 1969. S. 45 - 52. ISBN neuvedené

MARSENACH, J. - DRUENNE, F. 1974. Vollej-ball lenfant et l' activité physique et sportive. Paris : Armand Colin, 1974. 186 s. ISBN neuvedené

MORTON, J - COURT, M. 2002. Analysis of Goalkeepers ' Distribution. In: Insight. The F. A. Coaches Association Journal. Issue 3. Volume 5. London: The Football Association, 2002. s. 6-8. 
PAKUSZA, Z. 2005. Komplexný rozvoj hernej spôsobilosti mladých futbalistov. Dizertačná práca. Bratislava : FTVŠ UK, 2005. $146 \mathrm{~s}$.

PERÁČEK, P. 1992. Efektívnost’ športovej prípravy mladých futbalistov. Kandidátska dizertačná práca. Bratislava : FTVŠ UK, 1992. $251 \mathrm{~s}$.

PERÁČEK, P. et al. 1993. Teória a didaktika zvoleného športu futbal. Vysokoškolské skriptá. Bratislava : FTVŠ UK, 1993. 124 s. ISBN 80-223-0503-0

PERÁČEK, P. 1996. K niektorým otázkam štrukturalizácie obsahu hernej prípravy mladých futbalistov. In Tréner, č. 7. Bratislava : ÚFTS, SFZ, MŠSR, 1996. s. 18-24.

PERÁČEK, P. 1999. Osobitosti športovej prípravy reprezentačných družstiev mládeže SR vo futbale. Habilitačná práca. Bratislava : FTVŠ UK, 1999. $127 \mathrm{~s}$.

PERÁČEK, P. 2002. Stratégia športovej prípravy talentovanej mládeže s horizontom uplatnenia sa vo vrcholnom športe seniorov (s akcentom na prechod z mládežníckej kategórie do seniorskej). In Športová príprava mládeže. Bratislava : Národný inštitút športu, 2002.

PERÁČEK, P. 2004/a. Príprava reprezentačných družstiev mládeže vo futbale. 1. vyd. Bratislava : Slovenský futbalový zväz, 2004. 144 s. ISBN 80-969091-1-8.

PERÁČEK, P. 2004/b. Futbal. Riadenie - plánovanie - tréning. 4. vyd. Bratislava : Peter Mačura - PEEM, 2004. 214 s. ISBN 80-89197-09-4

PERÁČEK, P. 2012. Rukopis.

PERÁČEK, P. - HRNČIARIK, P. 2010. Analýza vybraných aspektov individuálneho herného výkonu brankárov v kategórii juniorov vo futbale. In: Zborník vedeckých prác katedry hier. Bratislava : FTVŠ UK, 2010. str. 55 - 68. ISBN 978-80-8113-021-2

REEP, C - BENJAMIN, B. 1968. Skill and chance in association football. In: Journal of the Royal Statistical Society. London : E \& FN Spon, 1968. s. 131.

REILLY, T. 1994. Physiological profile of the player. In EKBLOM, B. Football (Soccer). Oxford : Blackwell Scientific, 1994. s. 78-94.

REILLY, T. 2001. Measuring Heart Rate Response to Exercise. In Insight. The F. A. Coaches Association Journal. Issue 1. Volume 5. London: The Football Association, Winter 2001. s. 45-46.

ROUXBURGH, A. 2006. Liga Mistrů - kritérium úrovně. In: Fotbal a trénink. č.4. Praha : ÚČFT, 2006. s. $12-13$.

RUIZ, L. 2001. Soccer - Secrets to success. Madrid: Reedswain Publishing, 2001. 276 s. ISBN 18-909-4670-2 SCHNABEL, G. et al. 1994. Trainingswissenschaft: Leistung, Training, Wettkampf. Berlin : Sportverlag, 1994. $134 \mathrm{~s}$.

SINGER, R. 1972. The psychomotor domain: movement behaviors. Philadelphia : Lea \& Febiger, 1972. 417s. ISBN neuvedené

SLOVÍK, J. et al. 1989. Hádzaná. Športový tréning. Bratislava : Šport, STV, 1989. $232 \mathrm{~s}$.

SMITH,S. 2004. Goalkeeping for soccer. Leeds : Coachwise Ltd, 2004. 70s. ISBN 1-902523-66-0

SMITH, S. 2005. Goalkeeping practices. Leeds : Coachwise Ltd, 2005. 40s. ISBN 1-876554-54-1

STEIHLER, G., KONZAG, I. 1994. Leistungskultur und Handlungsregulation in den Sportspielen. In Sportspiele. č.4. Berlin : Sportverlag, 1994. 110s.

STEINER, F. 2005. Česká brankářská fotbalová škola. In: Fotbal a trénink. č.1. Praha : ÚČFT, 2005. s. 5 - 7. TARKOVIČ, Š. 2000. Analýza hry brankára. In : PERÁČEK, P. a kol.: Majstrovstvá Európy do 21 rokov na Slovensku. Bratislava : Slovenský futbalový zväz, 2000, s. 41 - 49.

TARKOVIČ, Š. - LIPKA, J. 1998. Hodnotenie individuálneho herného výkonu a herného výkonu družstva s využitím počítačového programu. In Tréner. č. 18. Bratislava : SFZ, ÚFTS a MŠ SR, 1998. s. 34-39.

THISSEN, G.G. 2001. Torwartschule fur Kinder- und Jugendfusballer. Berlin : Sportverlag, 2001. 143s. ISBN 3-927570-06-0.

TOERING, T.T. et al. 2009. Self-regulation and performance level of elite and non-elite youth soccer players. In: Journal of Sport Sciences. 2009. s. $1509-1517$.

VERHEIJEN, R. 1998. The complete handbook of Conditioning for soccer. Leeuwarden : Uitgeverij eisma, 1998. 268 s. ISBN 1-890946-06-0

VOTÍK, J. 2003. Fotbal - trénink budoucích hvězd. Praha : Grada Publishing, 2003. 137 s. ISBN 80-247-0463-3. 
STUDIA SPORTIVA 2012/6, č. 2, s. 19-37

WINECK, J. 1997. Optimales Fussbaltraining. Das Konditionstraining des Fussballspielers. Grundlagen des Konditionstrainings. Erlangen : Permed, 1997.

WHALL, R. 2001. Time-motion analysis of the football goalkeeper. In: Master, J., King, G., Strüder, H., Tsolakidis, E., Osterbore, A.(eds.) Perspectives and profiles. Cologne: Sport und Buch Strauss, 2001, s. 1208. WILLIAMS, L. 1973. Anticipation and timing in motor skills. Health physical education. London : Reedflow, 1973. s. 120.

ZÁHORSKÝ, J. 2008: Efektívnost’ športovej prípravy mladých futbalistov. Dizertat'ná práca. Bratislava : FTVŠ UK, 2008. $144 \mathrm{~s}$. 